\title{
Does the native natural predacious mite, Neoseiulus womersleyi Schicha (Acari: Phytoseiidae), overwinter on apple trees in northern Japan?
}

\author{
Ken FunAYAMA* \\ Fruit-Tree Experiment Station, Akita Prefectural Agriculture, Forestry and Fisheries Research Center; Yokote, Akita 013-0102, \\ Japan
}

(Received 1 April 2009; Accepted 15 October 2009)

\begin{abstract}
Neoseiulus womersleyi is a potentially important biological agent for controlling Tetranychus urticae in apple orchards. However, overwintering sites of $N$. womersleyi in apple orchards have not been identified; therefore, the population dynamics of $N$. womersleyi and T. urticae on apple trees were investigated in Akita Prefecture, northern Japan, from April 2007 to March 2008. The population of T. urticae peaked on the leaves in mid-September. In contrast, the population of $N$. womersleyi rapidly increased and peaked in early October, and many adults were present until early November. Eggs of the predacious mite were not observed at all in early November. Adult females of $N$. womersleyi were found under rough bark in early December. $N$. womersleyi was significantly more abundant under rough bark containing many diapausing T. urticae females than under bark where the prey were few; however, the mean number of $N$. womersleyi early in March 2008 was significantly lower than in early December. Both N. womersleyi and T. urticae were collected using Phyto traps attached to apple twigs. Neither was captured between April and September, but the numbers of both increased rapidly in October.
\end{abstract}

Key words: Neoseiulus womersleyi; overwintering site; apple orchard; Tetranychus urticae

\section{INTRODUCTION}

The predacious mite Neoseiulus womersleyi Schicha is a native species of Japan and a natural enemy of Tetranychus species on various crops in this country (Shinkaji and Adachi, 1978; Hamamura, 1986). N. womersleyi is distributed from northern Hokkaido to southern Okinawa (Amano et al., 2004), and has been observed in commercial apple orchards in Akita Prefecture in recent years (Hongo and Funayama, 2004); however, the density of predacious mites in fruit tree orchards generally increases only after the spider mite numbers reach damaging levels (Kishimoto, 2002). This time lag is considered the primary reason why predacious mites cannot effectively control spider mites, but their effectiveness as a biological control agent could be improved if larger populations could be maintained on trees before spider mite populations begin to grow (Kawashima and Amano, 2006). Jung et al. (2004) suggested that the initial establishment and subsequent conservation of $N$. womersleyi are both important in the successful biological control of T. urticae in apple orchards.

Another native predacious mite, Typhlodromus vulgaris Ehara, has also been reported in apple orchards (Hongo and Funayama, 2004). This species overwinters in the cocoons of insects and in artificial microstructures (Phyto traps) attached to the twigs of woody plants (Kishi and Mori, 1979). Kawashima and Amano (2006) reported that $T$. vulgaris can also overwinter in Phyto traps (Koike et al., 2000) attached to the twigs, main branches, and trunks of Japanese pear until early spring. Such artificial microstructures attached to apple trees could possibly provide overwintering sites for $N$. womersleyi, which could in turn lead to an increase in $N$. womersleyi earlier in spring, coincident with the increase of the population of T. urticae. It is therefore necessary to clarify the hibernation habits of $N$. womersleyi on apple trees. Pre-

*E-mail: funayamak@pref.akita.lg.jp

DOI: 10.1303/aez.2010.171 
viously, overwintering $N$. womersleyi have only been observed on herbaceous plants (Kishi and Mori, 1979; Takahashi and Mori, 1979). On the other hand, Kishi and Mori (1979) reported that they found overwintering female adults of $N$. womersleyi in the calyx end basin of mature pear fruits in late autumn, suggesting that woody hosts could also provide overwintering sites for $N$. womersleyi.

In the present study, the distributions and densities of predacious mites and spider mites were investigated on apple trees throughout the year. A possible method to improve the effectiveness of $N$. womersleyi in the control of T. urticae on apples is discussed from the viewpoint of overwintering ecology.

\section{MATERIALS AND METHODS}

Apple orchard. The investigation was conducted from April 2007 to March 2008 in an apple orchard of the Fruit-Tree Experiment Station of the Akita Prefecture Agriculture, Forestry and Fisheries Research Center $\left(39.14^{\circ} \mathrm{N}, 140.32^{\circ} \mathrm{E}\right)$ in Yokote, Akita Prefecture. The orchard (15a) contained about 20 apple trees (Malus domestica 'Fuji'), which were all older than 30 years and about $4 \mathrm{~m}$ height. The pest control record for the orchard is shown in Table 1.

Seasonal fluctuations in mite numbers on leaves and rough bark of apple trees. Ninety apple leaves were sampled from three trees (i.e., 30 leaves per tree) at intervals of 10 days from June to October. Mites on sampled leaves were brushed into a glass Petri dish (120 $\mathrm{mm}$ in diameter) spread with dilute detergent using a brushing machine (DKI-7200; Daiki Co. Inc., Tokyo, Japan), and adult female spider mites and eggs of predacious mites were counted under a binocular microscope. Predacious mites were mounted on Hoyer's medium, the species was identified under a microscope, and adult females of each species were counted.

Pieces of rough bark (about $2 \times 3 \mathrm{~cm}$ ) were sampled from the three apple trees by stripping the bark from the surface of primary scaffold branches in early December 2007 and early March 2008. Each piece of bark was classified into one of two groups based on the number of individual diapausing female T. urticae, either many $(>30)$ or few $(<4)$. Few pieces of rough bark contained intermediate numbers of $T$. urticae because the distribution of overwintering individuals on apple trees is clumped (Narita and Takahashi, 1981). Moreover, rough bark samples containing few $(<4)$ individuals of $T$. urticae were also sampled similarly in early December 2007. The numbers of predacious mites were compared for each species between the following conditions: (1) bark pieces containing many and few T. urticae in December 2007, and (2) December 2007 and March 2008 for pieces with many $T$. urticae present. Mann-Whitney's $U$ test was used for the comparison.

Test of Phyto traps as an overwintering site. Phyto traps were constructed following the procedure of Koike et al. (2000), although the structure was modified slightly: a $2 \times 1 \mathrm{~cm}$ piece of Velcro

Table 1. Pest control record for the apple orchard in 2007

\begin{tabular}{|c|c|c|c|c|c|c|}
\hline $\begin{array}{c}\text { Time of } \\
\text { application }\end{array}$ & $\begin{array}{l}\text { Insecticide (\%AC, } \\
\text { formulation) }\end{array}$ & $\begin{array}{l}\text { Concentration } \\
(\mathrm{ppm})\end{array}$ & $\begin{array}{l}\text { Acaricide }(\% \mathrm{AC}, \\
\text { formulation })\end{array}$ & $\begin{array}{l}\text { Concentration } \\
(\mathrm{ppm})\end{array}$ & $\begin{array}{l}\text { Fungicide (\% AC, } \\
\text { formulation) }\end{array}$ & $\begin{array}{c}\text { Concentration } \\
(\mathrm{ppm})\end{array}$ \\
\hline \multirow[t]{2}{*}{ Mid-May } & flufenoxuron $(10, \mathrm{EC})$ & 33 & & & dithianon $(40, \mathrm{~F})$ & 200 \\
\hline & & & & & hexaconazole $(2, F)$ & 20 \\
\hline \multirow[t]{2}{*}{ Late May } & & & & & ziram $(25, F)$ & 500 \\
\hline & & & & & thiuram $(15, \mathrm{~F})$ & 300 \\
\hline Mid-June & thiacloprid $(30, \mathrm{WP})$ & 75 & & & manzeb $(75, \mathrm{WP})$ & 1,500 \\
\hline Late June & & & & & manzeb $(75, \mathrm{WP})$ & 1,500 \\
\hline \multirow[t]{2}{*}{ Mid-July } & clothianidin $(16, \mathrm{SP})$ & 40 & & & fosetyl (40,WP) & 500 \\
\hline & & & & & captan $(40, \mathrm{WP})$ & 500 \\
\hline \multirow[t]{2}{*}{ Late July } & & & etoxazole $(10, \mathrm{~F})$ & 50 & fosetyl (40,WP) & 500 \\
\hline & & & & & captan $(40, \mathrm{WP})$ & 500 \\
\hline Early Aug. & & & chlorfenapyr $(10, F)$ & 50 & kresoxim-methyl $(41.5, \mathrm{~F})$ & 208 \\
\hline Late Aug. & & & milbemectin $(1, \mathrm{EC})$ & 10 & kresoxim-methyl $(41.5, \mathrm{~F})$ & 208 \\
\hline
\end{tabular}

AC: active ingredient, WP: wettable powder, EC: emulsifiable concentrate, F: flowable, SP: water-soluble powder. 
(hooked surface) was stapled to a piece of transparent vinyl tape $(10 \times 1.5 \mathrm{~cm})$, and wool yarn was attached to the Velcro. Each Phyto trap was then attached to an apple twig using a double-arm clip such that the Velcro was in contact with the twig. The traps were washable and could be reused many times.

Within the orchard, 10 Phyto traps were attached to previous-year branches of three apple trees from April to October. The traps were collected at 7-d intervals and replaced with new traps. Collected traps were observed under a binocular microscope, and the numbers of spider mites and predacious mites in the traps were counted and identified to the species level.

\section{RESULTS AND DISCUSSION}

Seasonal fluctuations in predacious mites and spider mites on leaves in the apple orchard in 2007 are shown in Fig. 1. T. urticae was observed from late July and rapidly increased to a peak in midSeptember. Diapausing females of T. urticae were observed from early October. Panonychus ulmi Koch were observed from late June to early August, though their numbers were low (fewer than 20 individuals per 90 leaves). N. womersleyi was observed from early September; the population density rose rapidly to a peak in early October, and the adults were still observed in early November. $T$. vulgaris was also observed from early September; the population density rose rapidly and peaked in early October, and the adults were observed until late October. $N$. womersleyi on the leaves of apple trees have been reported to increase when $T$. urticae populations grow (e.g., Hongo and $\mathrm{Fu}-$ nayama, 2004; Jung et al., 2004), although the increase was not observed until August in the present study (Fig. 1). Regarding the pesticides sprayed in this orchard, an insect growth regulator (flufenoxuron) and neonicotinoids (thiacloprid and clothianidin) have been shown to be harmless for N. womersleyi (Funayama, unpublished data), as has chlorfenapyr (Amano et al., 2004); however, the acaricides etoxazole and milbemectin have been found to be slightly or moderately harmful to $N$. womersleyi (Amano et al., 2004). Therefore, the occurrence of $N$. womersleyi on apple leaves may have been suppressed by spraying these acaricides from late July to late August.

Adult $N$. womersleyi diapause in November in Hiroshima Prefecture, southwestern Japan (Hamamura, 1982), and in mid-September in Sapporo city, Hokkaido Prefecture, northern Japan (Takahashi and Mori, 1979). The induction of diapause in adult predacious mites is reported to occur when they have completed egg deposition (Hamamura, 1982). In the present study, the number of eggs of predacious mites increased from early September and peaked in late September to early October;

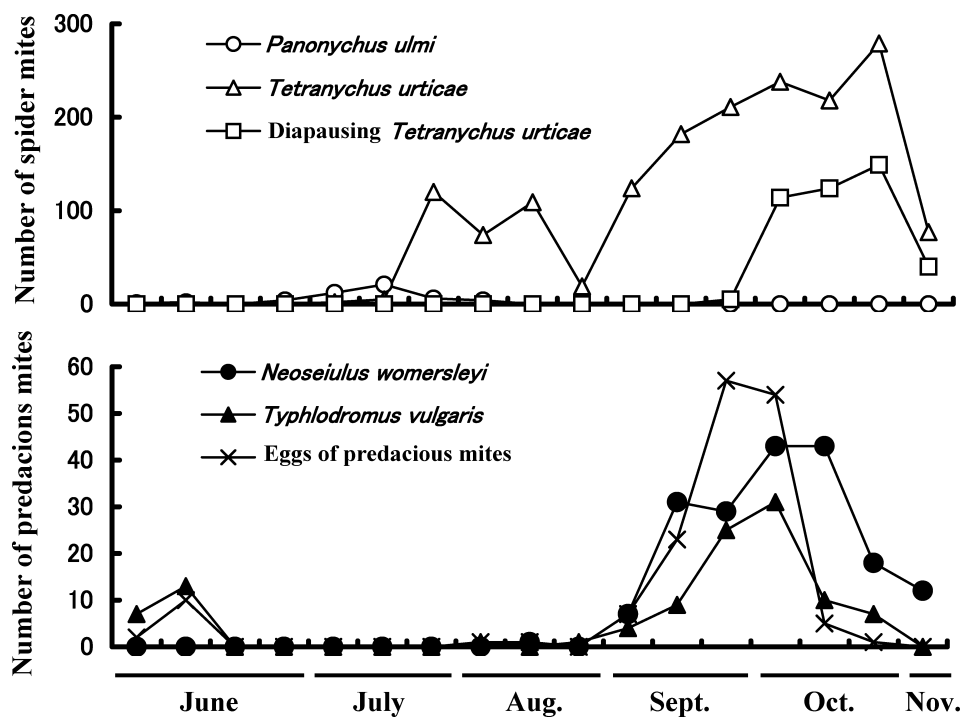

Fig. 1 Seasonal fluctuations in the numbers of adult females and eggs of predacious mites and spider mites on the leaves of apple trees in the orchard from June to November 2007. Ninety apple leaves were sampled from three trees (i.e., 30 leaves per tree) at intervals of $10 \mathrm{~d}$. 
thereafter, the number decreased until late October and no eggs were observed in early November (Fig. $1)$. This observation indicates that most $N$. womersleyi and T. vulgaris entered diapause after early November in Akita Prefecture. The numbers of predacious mites and T. urticae found under pieces of rough bark of apple trees in early December 2007 are shown in Table 2. Adults of N. womersleyi and T. vulgaris were found under rough bark; all were females. This observation suggests that at least some adult females of the $N$. womersleyi population overwintered on apple trees in the orchard, as is the case for T. vulgaris.

The mean number of $N$. womersleyi was significantly larger under rough bark that hosted many $(>30)$ T. urticae than under bark that hosted few $(<4)$ T. urticae $(p<0.01)$ (Table 2). There was no significant difference between the mean numbers of T. vulgaris observed under rough bark at the two densities of T. urticae $(p>0.01)$ (Table 2). This ob- servation suggests that the number of $N$. womersleyi respond to the aggregation size of T. urticae infesting rough bark, even in the selection of overwintering sites. On the other hand, the mean number of $N$. womersleyi observed under rough bark containing many diapausing female $T$. urticae in early March 2008 was significantly lower than that observed in early December $2007(p<0.01)$ (Table 2 ). There was no significant difference between the mean numbers of $T$. vulgaris observed under rough bark in the same two periods ( $p>0.01$ ) (Table 2). This observation suggests that the rough bark of apple trees may not provide a particularly suitable overwintering site for $N$. womersleyi; however, it remains unknown whether the survival rate of $N$. womersleyi declined during the winter. Thus, more detailed investigation will be necessary to clarify the selection of overwintering sites by $N$. womersleyi on apple trees.

Seasonal fluctuations in the numbers of adult fe-

Table 2. The numbers of predatory mites and Tetranychus urticae found in the bark of apple trees in the orchard in early December 2007 and early March 2008

\begin{tabular}{|c|c|c|c|c|c|c|}
\hline \multirow{3}{*}{ Species } & \multirow{3}{*}{$N$} & \multicolumn{3}{|c|}{ Number observed in old bark (Mean \pm SE) } & \multirow{3}{*}{$\mathrm{a}$} & \multirow{3}{*}{$\mathrm{b}$} \\
\hline & & \multicolumn{2}{|c|}{ Dec. 2007} & \multirow{2}{*}{$\begin{array}{c}\text { Mar. } 2008 \\
\text { With many }(>30) \\
\text { T. urticae }\end{array}$} & & \\
\hline & & $\begin{array}{c}\text { With many }(>30) \\
\text { T. urticae }\end{array}$ & $\begin{array}{l}\text { With few }(<4) \\
\text { T. urticae }\end{array}$ & & & \\
\hline Tetranychus urticae & 42 & $73.4 \pm 6.6$ & $0.5 \pm 0.2$ & $89.2 \pm 9.1$ & $* *$ & \\
\hline Neoseiulus womersleyi & 42 & $1.4 \pm 0.5$ & $0.1 \pm 0.1$ & $0.3 \pm 0.1$ & $* *$ & $* *$ \\
\hline Typhlodromus vulgaris & 42 & $0.2 \pm 0.1$ & $0.1 \pm 0.0$ & $0.3 \pm 0.2$ & & \\
\hline
\end{tabular}

Asterisks (**) indicate significant difference between (a) number of bark pieces containing many and few T. urticae in December 2007 within each species, and (b) number of $N$. womersleyi on bark with many T. urticae in December 2007 and March 2008 $(p<0.01$, Mann-Whitney $U$-test).

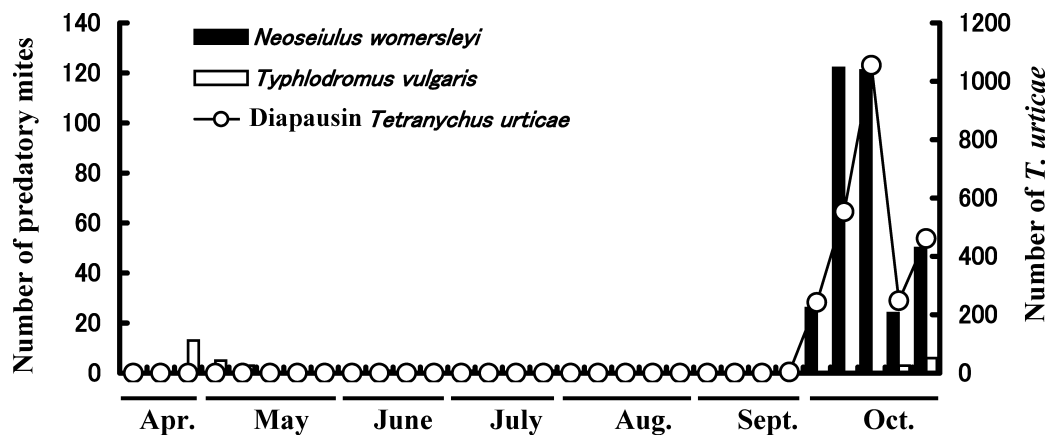

Fig. 2 Seasonal fluctuations in the numbers of adult female predacious mites and Tetranychus urticae in Phyto traps attached to apple twigs in the orchard from April to October, 2007. Ten Phyto traps were attached to each of three apple trees and were collected for observation and replaced at 7-d intervals. 
male of predacious mites and T. urticae in Phyto traps attached to twigs of apple trees in the orchard from April to October 2007 are shown in Fig. 2. Adult female T. vulgaris were collected in Phyto traps from late April to early May and in October. This observation suggests that $T$. vulgaris used the Phyto traps not only as overwintering sites but also as a refuge. On the other hand, no $N$. womersleyi were collected in the traps from April to September (Fig. 2), but numbers increased through the first weeks of October, suggesting that $N$. womersleyi used the Phyto traps only for overwintering. This suggests that Phyto traps are not suitable for measuring the population dynamics of $N$. womersleyi on apple trees in summer; however, it is possible that $N$. womersleyi used Phyto traps as overwintering sites, because the increasing number of adult female $N$. womersleyi collected in the traps was synchronized with increases in the number of diapausing female T. urticae in October. In addition, more adult female $N$. womersleyi were collected in Phyto traps than from rough bark (Table 2 and Fig. 2). Kawashima and Amano (2006) reported that $T$. vulgaris can overwinter in Phyto traps (Koike et al., 2000) on Japanese pear until early spring; therefore, installation of artificial microstructures such as Phyto traps in apple orchards may maintain a higher population density of predacious mites through the winter and thus may enable the $N$. womersleyi population to better control the size of the T. urticae population. Detailed investigations are necessary to determine whether the presence of artificial microstructures can in fact increase the population density of $N$. womersleyi in apple orchards in early spring.

\section{ACKNOWLEDGMENTS}

I thank Mr. K. Fujii of the Akita Fruit-Tree Experiment Station for his assistance with the fieldwork.

\section{REFERENCES}

Amano, H., Y. Ishii and Y. Kobori (2004) Pesticide susceptibility of two dominant phytoseiid mites, Neoseiulus californicus and $N$. womersleyi, in conventional Japanese fruit orchards (Gamasina: Phytoseiidae). J. Acarol. Soc.
Jpn. 13: 65-70.

Hamamura, T. (1982) Studies on the diapause of the predacious mite, Amblyseius longispinosus (Evans) (Acarina: Phytoseiidae). Bull. Fruit Tree Res. Stn. E4: 77-89 (in Japanese with English summary).

Hamamura, T. (1986) Studies on the biological control of Kanzawa spider mite, Tetranychus kanzawai Kishida by the chemical resistant predacious mite, Amblyseius longispinosus (Evans) in tea fields (Acarina: Tetranychidae, Phytoseiidae). Bull. Tea Res. Sta. 21: 121-201 (in Japanese with English summary).

Hongo, K. and K. Funayama (2004) Phytoseiid mites on apple trees in southern Akita prefecture. Ann. Rep. Plant Prot. North Japan 55: 256-258 (in Japanese).

Jung, C., S. Han and J. Lee (2004) Release strategies of Amblyseius womersleyi and population dynamics of Amblyseius womersleyi and Tetranychus urticae: II. Test of two release rates on apple. Appl. Entomol. Zool 39: 477-484.

Kawashima, M. and H. Amano (2006) Overwintering phenology of a predacious mite, Typhlodromus vulgaris (Acari: Phytoseiidae), on Japanese pear trees, observed with Phyto traps. Exp. Appl. Acarol. 39: 105-114.

Kishi, N. and H. Mori (1979) The seasonal fluctuations of four species of phytoseiid mites in Sapporo, Hokkaido (Acari: Phytoseiidae). Mem. Fac. Agric. Hokkaido Univ. 11: 245-257 (in Japanese).

Kishimoto, H. (2002) Species composition and seasonal occurrence of spider mites (Acari: Tetranychidae) and their predators in Japanese pear orchards with different agrochemical spraying programs. Appl. Entomol. Zool. 37: 603-615.

Koike, A., H. Nemoto and H. Amano (2000) New trap for survey of species structure and seasonal dynamics of phytoseiid mites on Japanese pear trees (Acari: Phytoseiidae). Jpn. J. Appl. Entomol. Zool. 44: 35-40 (in Japanese with English summary).

Narita, H. and Y. Takahashi (1981) Studies on the ecology and control methods of the two-spotted spider mire, Tetranychus urticae Koch. I. The overwintering sites and survival rate in heavy snow districts. Bull. Akita FruitTree Exp. Stn. 13: 33-45 (in Japanese with English summary).

Shinkaji, N. and T. Adachi (1978) The effect of certain pesticides and the predacious mite Amblyseius longispinosus (Evans) (Acarina: Phytoseiidae). Bull. Fruit Tree Res. Stn. E4: 77-89 (in Japanese with English summary).

Takahashi, K. and H. Mori (1979) Studies on overwintering of Amblyseius longispinosus (Evans) (Acari: Phytoseiidae). Mem. Fac. Agric. Hokkaido Univ. 11: 258-264 (in Japanese). 